J. Product. \& Dev., 23(1): 99-109 (2018)

\title{
ECOLOGICAL AND CONTROL STUDIES ON Spodoptera littoralis (BOISD.) INFESTING COWPEA CROP
}

Rehab E. Abd-Allah ; Mohanna, A. H. ${ }^{2}$;El Sharkawy, H. M. ${ }^{2}$ and M. S. ${ }^{l}$ Hashem

1. Plant Protection Research Institute, A.R.C., Dokki, Giza-Egypt.

2. Department of Plant Production, Faculty of Technology \& Development, Zagazig University, Egypt.

\section{ABSTRACT}

The present work is a trial to study the population density of Spodoptera littoralis (Boisd.) on cowpea, Vignaun guiculata (L.) Walpis plant. Also, to evaluate the effect of some insecticides against the pest under field conditions. Field experiments has been done at Zagazig District, Sharkia Governorate, during the seasons of 2015 and 2016. With the completion of the work, egg-masses and larval stages were fluctuated in the mean number. On other word, population density was higher with appreciable rate in 2015 than 2016 with mean number of 10 egg-mass, $366 l$ arva/sample and 7.75egg-mass, 279.16larva /sample in both seasons, respectively.

The population density of S. littoralis larvae on cowpea plants differed in the two seasons and appeared highly average number644 larva/sample inthe first season and536larva/sample in the second season. In conclusion, certain points can be deduced from this work. The patterns observed during and after treatment with different regimes were:

1-Two peaks in the first season, and three in the second for larval population of S. littoralis

2-Population of $S$. littoralis larvae differs during the growing stages of cowpeaplant.

3-The infestation percent was highly in flowering and reproductive stages(73.33\%) in season 2015 while it recorded $88.0 \%$ in 2016 in the vegetative stage. Regarding to the efficacy of treated insecticides on $S$. littoralis data revealed that Match had the potential reduction on the larvae in the two seasonsrecording $88.67 \%$ initial effect and the residual was $92.44 \%$.Reduction values were somewhat low at the onset of treatment, but starting from 5days to rose up sequentially till the end period. The poorly effect was recorded in the case of the carbamate Methomate. 
Fortunately, the latent effects of the tested compounds are seem to be promising in regard to the rate of reduction of $S$. littoralis.

Conclusively, the acquaintance of the number of generations of S. littoralis infesting cowpea plants can help in implementation of an integrated pest management program against that pest.

Key words: Spodoptera littoralis (Boisd.), Cowpea, Ecology, Insecticides.

\section{INTRODUCTION}

Cowpea, Vignaun guiculata (L.) Walp, a multifunctional crop providing food for man and livestock and serving as a valuable dependable revenue generating commodity in many parts of the world.Cowpea belongsto the family of Papilionaceae (Leguminosae-Papilionoideae, Fabaceae).Cowpea grain contains $23.4 \%$ protein and good quantity of thiamine (vitamin $\mathrm{B}_{1}$ ), riboflavin (vitamin $\mathrm{B} 2$ ) and niacin(vitamin b3) and richer than cereals in iron and calcium content .Cowpea leaves are a significant source of Beta-carotene and ascorbic acid (vitamin C). Cowpeans seed grain used as food, supplement very well the protein deficiency of the predominantly carbohydrate (Ngalamu et al., 2015). Metwally (1999) declared that cowpea was attacked by different serious pests. The most insects attacking cowpea plants are the white flies Bemisia spp. , Aphids ,green stink bug, Nezara viridula L., Spodoptera littoralis (Boisd.), Empoa scadecipiens Paoli, and Thrip stabaci Lindeman .The cotton leaf worm, $S$. littoralis is considered as oneof the most series pests for different crops in Asia, Africa and Europe (Smagghe and Degheele,1997).

In Egypt, it is one of the most destructive agricultural lepidopterous pest within its subtropical and tropical range (Hosny et al.,1986). The cotton leaf worm, $S$. littoralis is a serious economic pest. It is apolyphagous on a wide varieties of plants, mainly attacks cotton in summer and Egyptian clover between plant to another,the pest frequently attacks vegetable plantations as temporary alternanthosts, and may cause severe damage to them Younis (1992). The effect of chemical pesticides on S. littoralis was extensively studied by several investigators (Anwar and El-Mageed 2005, Elgohary 2014 and Al-Shannaf et al., 2006 ). Desuky et al. (2005) studied the efficacy of Match (insect growth regulator) using the recommended field rate to control the cotton leaf worm in cotton fields. 
This work aimed to study the population density of S. Littoralis on cowpea crops, the combined effects of temperature and relative humidity in addition to estimating the efficacy of some insecticides against it.

\section{MATERIALS AND METHODS}

\section{Ecological studies:}

\subsection{Population density of Spodoptera littoralis on cowpea plant:}

Investigations were carried out at Zagazig District, Sharkia Governorate during two successive seasons 2015and 2016. The experimental area (8 kirrat) was cultivated by cowpea variety Dokki 331 on $26^{\text {th }}$ April in the first season and on $2^{\text {nd }}$ May in the second to evaluate the population density of $S$. littoralis. The area was divided into 4 replicates distributed randomly. Normal agricultural practices were followed except pesticides applications. When the age of cowpea plants reached 15 days, random samples of 100 cowpea plants (25 plant from each replicate)were inspected weekly in the field. The samples represented different strata of the plant. Egg-masses and all larval instars were counted and recorded . Thedaily records of mean temperatures and mean relative humidity during 2015 and 16 were got from the Agrometeorological Station at Zagazig city which located nearly to the experimental area .The obtained results were statistically analyzed;correlation coefficient was estimated according to Costat (1990).

Infestation percent[(number of infested plants/total number of inspected plants) $\times 100$ and damage (Number of larvae / Plant) were calculated.

\section{Control studies:}

\subsection{Insecticides used:}

A. Trade name: Match $5 \%$ EC.

Common name: Lufenuron.

Chemical name: (Rs)-1-[2,5-dichoro-4-(1,1,2,3,3,3-hexa fluoropropoxy) phenyl]-3- (2,6-difluorobenzoyl)urea.

B. Trade name: Betavant $14.5 \% \mathrm{SC}$.

Common name: Indoxacarb.

Chemical name: Methyl(s)-N-[7-chloro-2,3,4a,5- tetra hycdro -4a (methoxycarbonyl) indeno [1, 2-e][1,3,4]oxadiazine-2-yl carbonyl]-4(Trifluoromethoxy) Carbanilate.

C. Trade name: Methomate $90 \%$ SP.

Common name: Methomyl.

Chemical name : s-methyl $\mathrm{N}$-(Methyl carbamoyloxy) thioacetimidate. 


\subsection{Effect of the tested insecticides against Spodoptera littoralis on cowpea plant:}

To study the efficacy of the tested insecticides against $S$. Littoralis larvae, an area of about (16 Kirrat) was divided into 4 equal plots(3treatments in addition to the control), and each treatment replicated four times. Treatments were arranged in a Randomized Complete Block Design. Dokki 331 cowpea variety was sowed at Zagagig District, Sharkia Governorate during both seasons 2015 and 2016. A Knapsack sprayer (20 litter) was used and filled with recommended concentrations of each insecticide. The plot of control was sprayed with water. Numbers of different larval instars of S. littoralis on 100 cowpea plants were counted directly while newly hatched ones were neglected from counting ( 25 cowpea plants were chosen randomly in each replicate) before treatment and examined after3,5,7and10 days for Match and 1,3,5,7 and 10 for each of Betavaunt and Methomate. The reduction percentages of $S$. littoralis egg-masses and larvae were calculated according to the equation of Hinderson and Telton (1955). For insecticide compounds the initial kill was represented with the reduction in population after one day of application,while in case of IGRs it occurred after 5 days of spraying (Gomaa et al., 1996; Badr et al., 2000 and Khedr, 2002). Residual effects of insecticide compounds were calculated as the average reduction after 3, 5, 7 and 10 days after application. While for IGR calculated as after 7and 10 days after application.

\section{RESULTS AND DISCUSSION}

\section{Ecological studies}

\subsection{Population density of Spodoptera littoralis on cowpea plant:}

Data in Table (1) showed the population density of S. littoralis eggmasses and larval stages on cowpea plant during seasons 2015and16.Results revealed thategg- masses appeared lately at the first season showing three peaks during the two seasons. The highest one was 27 egg -masses/ sample at the end of June in 2015 and 18 egg-masses/sample in the third week of June 2016 .Larvae of $S$. littoralis showed two peaks in the first season. The highest one was 644larva/ sample appeared in the first week of July while the second 552 larva/sample which appeared at the $2^{\text {nd }}$ week of June. On the other hand, the population of larvae during season 2016 fluctuated during the other monthsshowing three peaks,the highest was 536 larva/sample appeared in the first week of July.The present results were near similar with Shahzad et al.(2014) who reported that cotton leaf worm population build 
Table (1). Weekly mean numbers of S. littoralis, mean temperature and R.H. \% on cowpea at Sharkia Governorate during seasons 2015 and 2016:

\begin{tabular}{|c|c|c|c|c|c|c|c|c|c|}
\hline \multirow{3}{*}{$\begin{array}{c}\text { Date of } \\
\text { inspection }\end{array}$} & \multicolumn{4}{|c|}{ Season 2015} & \multicolumn{5}{|c|}{ Season 2016} \\
\hline & \multicolumn{2}{|c|}{ Number/ 100 plant } & \multicolumn{2}{|c|}{ Mean } & \multicolumn{2}{|c|}{ Number/ 100 plant } & \multicolumn{3}{|c|}{ Mean } \\
\hline & $\begin{array}{c}\text { Egg- } \\
\text { masses }\end{array}$ & Larvae & $\underset{{ }^{0} \mathrm{C}}{\text { Temp }}$ & $\begin{array}{c}\text { R.H. } \\
\%\end{array}$ & $\begin{array}{c}\text { Date of } \\
\text { inspection }\end{array}$ & $\begin{array}{c}\text { Egg- } \\
\text { masses }\end{array}$ & Larvae & $\begin{array}{c}\text { Temp. } \\
{ }^{0} \mathbf{C}\end{array}$ & $\begin{array}{c}\text { R.H. } \\
\%\end{array}$ \\
\hline $11 / 5$ & 0 & 9 & 24 & 47.4 & $17 / 5$ & 3 & 5 & 30.8 & 35.42 \\
\hline $18 / 5$ & 6 & 11 & 23.8 & 50.4 & $24 / 5$ & 9 & 9 & 25.2 & 46 \\
\hline $25 / 5$ & 3 & 192 & 27.2 & 39.4 & $31 / 5$ & 6 & 148 & 26 & 41.71 \\
\hline $1 / 6$ & 9 & 240 & 26.5 & 40.2 & $7 / 6$ & 12 & 324 & 32.7 & 27.14 \\
\hline $8 / 6$ & 9 & 500 & 26.1 & 48.2 & $14 / 6$ & 9 & 428 & 29 & 44.42 \\
\hline $15 / 6$ & 12 & 552 & 25.8 & 55 & $21 / 6$ & 18 & 304 & 30 & 46.28 \\
\hline $22 / 6$ & 15 & 436 & 28.2 & 47 & $28 / 6$ & 9 & 460 & 30.71 & 57 \\
\hline $29 / 6$ & 27 & 580 & 27.2 & 48.1 & $5 / 7$ & 12 & 536 & 29.71 & 58.42 \\
\hline $6 / 7$ & 12 & 644 & 27 & 56.2 & $12 / 7$ & 9 & 280 & 30.14 & 56.14 \\
\hline $13 / 7$ & 18 & 488 & 27.7 & 53.8 & $19 / 7$ & 3 & 440 & 30.2 & 50.71 \\
\hline $20 / 7$ & 9 & 460 & 28.8 & 52.8 & $26 / 7$ & 3 & 320 & 30.14 & 54.42 \\
\hline $27 / 7$ & 0 & 280 & 30 & 45.4 & $2 / 8$ & 0 & 96 & 30.28 & 58.14 \\
\hline Total & 120 & 4392 & & & & 93 & 3350 & & \\
\hline Mean & 10 & 366 & & & & 7.75 & 279.16 & & \\
\hline $\begin{array}{l}\mathbf{r}(\text { Egg- } \\
\text { masses) }\end{array}$ & & & 0.34 & $\begin{array}{c}0.22 \\
-\end{array}$ & & & & 0.43 & -0.19 \\
\hline r (Larvae) & & & 0.71 & 0.59 & & & & 0.60 & 0.68 \\
\hline
\end{tabular}

(r): Correlation coefficient

up initiated in July and continued a constant threat till the end of cotton season. Hence management practices should be focused from July and be continue till the end of October.

The correlation between two weather factors [temperature $\left({ }^{0} \mathrm{C}\right)$ and relative humidity $(\mathrm{RH} \%)]$ and the cotton leaf worm egg-masses and larvae on cowpea plant cleared with (r) values. The obtained data indicated positive correlation between the population of $S$. littoralis and the temperature). In contrast, a negative in $\mathrm{RH}$. for the egg-masses. The $(\mathrm{r})$ values were $(\mathrm{r}=0.34$ $\&-0.22$ ) for temperature and R.H., respectively during season 2015 on the $S$. littoralis population. Regarding to the season of 2016, the two phenomena were recorded $(0.43 \&-0.19)$ as the for mentioned, respectively. The relationship between number of larvae and both of temperature and R.H. was positive where (r)values were $(0.71 \& 0.59)$ for season 2015 while were $(0.60 \& 0.68)$ in the second season. These results similar with Somaa 
(2016) who evaluated the effect of temperature and relative humidity on the population density of egg-masses of S. littoralis.

The effect of temperature was significant and positive while the relative humidity effect was negative. Also, these results are in agreement with Taha et al. (2012) who declared that temperature and relative humidity had significant effect on population density of $S$. littoralis where (r)values were $(0.58 \& 0.72)$, respectively.

\subsection{Effect of the cowpea plants age on S. littoralis population during seasons 2015 and 2016:}

Data in (Table 2) explicate the percent infestation and damage of $S$. littoralis during growing stages of cowpea plant. The infestation percent and damage were low at the germination stage .As for the infestation was 61.5 $\%$ in vegetative stage and rose up to73.33\% in flowering and reproductive stages at the first season 2015. Damage (no. of larvae / plant) was highly with a level of 4.81 larvae / plant at flowering and reproductive stage. The infestation percentage was increased at vegetative stage until reached $88 \%$, while it was 67.33 at the next stage.

Table (2). Effect of plant age on population of S. littoralis on cowpea crops during seasons 2015 and 2016

\begin{tabular}{|c|c|c|c|c|}
\hline \multirow{2}{*}{ Growth stages } & \multicolumn{2}{|c|}{2015} & \multicolumn{2}{c|}{2016} \\
\cline { 2 - 5 } & $\begin{array}{c}\text { Infestation } \\
\%\end{array}$ & $\begin{array}{c}\text { Damage (no. } \\
\text { of larvae/leaf) }\end{array}$ & $\begin{array}{c}\text { Infestation } \\
\%\end{array}$ & $\begin{array}{c}\text { Damage (no. } \\
\text { of larvae/leaf) }\end{array}$ \\
\hline Germination & 6 & 0.1 & 4 & 0.07 \\
\hline Vegetative & 61.5 & 3.71 & 88 & 3.01 \\
\hline $\begin{array}{c}\text { Flowering and } \\
\text { reproduction }\end{array}$ & 73.33 & 4.81 & 67.33 & 3.55 \\
\hline
\end{tabular}

\section{Controltrials}

\subsection{Effect of certain insecticides against Spodoptera littoralis}

All the investigated insecticides at the recommended concentrations wereexhibited appreciable reduction against the infestation of $S$. littoralis on cowpea plants compared to control. The initial effect was measured as the reduction percentages of $S$.littoralis larvae at the first day post treatment for Betavaunt and Methomate and at the fifth day post treatment for Match .The differences in the times of initial effect was due to the mode of action of each insecticide. Data of (Table 3) showed that ,through the season 2015 the initial effect of Match, Betavaunt and Methomate recorded $88.67,77.19$ 
and $88.97 \%$ reduction,respectivelywhereas in the second season(2016) Match recorded the highest initial effect which was $84.91 \%$. The values of residual effect showed that Match exhibited the highest value which was $92.44 \%$ in the first season and $87.71 \%$ in the second. The obtained results revealed that the residual effect of IGRs increased than that of initial effects during the two successive seasons, indicating that the effectiveness of Match increased with increasing the time. The present results corroborates those of Desuky et al. (2012) who evaluated the effect of Dimilin (IGR) on $S$. littoralis under field conditions. Their results indicated that the initial effect of tested IGR induced reduction in the rate of $S$. littoralis infestation, as it recorded (77.295\%) reduction in season $2008,71.8 \%$ during season 2009 and the residual effects were 82.60 and76.00 \%,respectively. Also, the present results are near similar with Saidetal.(2016) who evaluated the insecticides, lufenuron and in doxacarb, which caused reduction85.6\% and $77.6 \%$,respectively.In addition, the results agree with that obtained by Elgohary (2014), and Abdel-Aal et al.(2009).

Conclusively, the acquaintance of the number of generations of S. littoralis infesting cowpea plants can help in implementation of an integrated pest management program against that pest.

\section{REFERENCES}

Abdel-Aal, A.T.E.; T.A. El-Sheikh and A. M. Farag (2009).Effectiveness of insect growth regulators on the cotton leafworm, Spodopteralittoralis (Boisd.) population on cotton fields at Menofia Governorate . Egyptian .J. Agric .Res., 87 (2):59-72.

Al-Shannaf,H.M.H.;W.M.H.DesukyandS.M.Abdel-Halim(2006).Effect of some compounds on cotton leafwormSpodopteralittoralis(Boisd.) and their predators. Egyptian Sci., 21(4B):646-660.

Anwar, E.M. and A.E.M. Abd El-Mageed(2005) .Toxicity impacts of certain insect growth regulators on some biochemical activities of the cotton leafworm. Egyptian J. Agric Res., 83 (3). ارقام الصفحات

Badr ,N.A.;S.A.Mohamed andS.M.A. El-Hallem(2000).Effect of seed oil extracts on the different developmental stages of the Egyptian cotton leafworm, Spodoptera littoralis. Egyptian J. of Biological Pest Control, 10(1/2):39-50.

Costat Statistical Software(1990). Microcomputer Program Analysis Version,4.20,CoHortSoftware,Berkeley,CA. 
Desuky, W.M.H.; M.M.A. Khedr; S.I. Yousif-Khalil and S.M.A. ElShakaa(2005). Field and biochemical studies on some compounds against cotton leafworm, Spodoptera littoralis (Boisd.). Egyptian J. Agric. Res., 83(3):1087-1105.

Desuky ,W. M. H.; A.A. El-Berry ; R.E. Omar ;M. M. Khattab and Y.A. Metwaly (2012).Effect of certain bio and chemical insecticides on cotton leafworm, Spodoptera littoralis (Boisd.) andsome associated predators under field condition. Egyptian J.Agric.Res.,90(4):15131529.

Duncan,D. B. (1955) . Multiple ranges and multiple F. test .Biometrics, 11:1- 41 .

Elgohary, R. A. Laila (2014). Ovicidal and larvicidal activities of three insect growth regulators against the cotton leafworm, Spodoptera littoralis (Boisd.). J. Plant Prot. and Path., Mansoura Univ., 5 (1): 111.

Gomaa, E.A.A.; G.M. Moawad ;W.M.H. Desuky; A.A. El-Sheikh and S.A.A. Raslan(1996). Feeding response, biological and toxicological potent of some IGRs Spodoptera littoralis. Egypt.J.Agric.Res.,74(1):91-100.

Hinderson, C.F. and E.W. Telton (1955). Test with acaricides against brown white mite. J. Econ. Entomol., 48:157-161.

Hosny, M.M.; C.P. Topper ;G.G. Moawad and G.B. El-Saadany (1986).Economic damage thresholds of Spodoptera littoralis (Boisd.) (Lepidoptera: Noctuidae) on cotton in Egypt.Crop Protection, 5:100- 104 .

Khedr,M.M.(2002).Effect of some plant extracts and insect growth regulators applier to control cotton leafworm on honey bees, Apismellifera L..M.Sc. Thesis, Fac. Agric. Zagazig Univ. „Egypt :204pp..

Metwally, A.G. Samia (1999).Effect of planting date and certain weather factors on the population fluctuation of three insect pests infesting kidney beans in Qualyobia Governorate. Egyptian J. Agric. Res.,77(1):139-149.

Ngalamu, Tony; James Odra and Nixon Tongun (2015). Cowpea productionhandbook.https://www.reasearchgate.net/publication/284900187.

Said,A.A.A.;M .M. Kady and H. M. H. Al-Shannaf (2016). Toxicolgical and biochemical effects of some recommended and alternative compounds on cotton leafworm Spodoptera littoralis (Boisd.) (Lepidoptera:Noctuidae) in cotton fields. J. Plant Prot. and Path., Mansoura Univ., 7 (3): 205-213. 
Shahzad , M. S. ; H. Asifa ; S. Ahmad; A. M. M. Aslam ; N. Khan ; K. Mehmood and S. Fared (2014) . Modelling population dynamics of cotton leafworm (Spodoptera littoralis) (Lepidopter: Noctuiidae) in relation to meteorologicalfactors in Multan, Punjab, Pakistan. International Journal of Agronomy and Agricultural Research (IJAAR), 5( 1) : 39-45.

Smagghe, G. and D. Degheele (1997). Comparative toxicity and tolerance for the ecdysteroidmimic tebufenozide in a laboratory strain of cotton leafworm (Lepidoptera: Noctuidae).. J. Econ. Ent, 90: 278282.

Somaa,H.M.H(2016). Effect of certain weather factors and some natural enemies on the population density of the bollworms and cotton leafworm at Kafr El-Sheikh Governorate, Egyptian J. Plant Prot. and Path., Mansoura Univ., 7(2): 161 - 169.

Taha, M. A.; Abdel Wahab A. Horia; Mahmoud I. Hanaa and Abdel Hamed S. Ghada (2012). Population density of some insect pests infesting globe artichoke plantations in relation to certain ecological factors at Dakahalia Governorate. J. Plant Prot. and Path., Mansoura Univ., 3 (4): 347 - 353.

Younis, A.M.(1992). Some biological aspects of cotton leafworm Spodoptera littoralis (Boisd.) under different constant temperature regimes. Bull. Ent. Soci. of Egypt, 70:171-180. 
دراسات بيئية ومكافحة علي دودة ورق القطن التي تصيب محصول اللوبيا

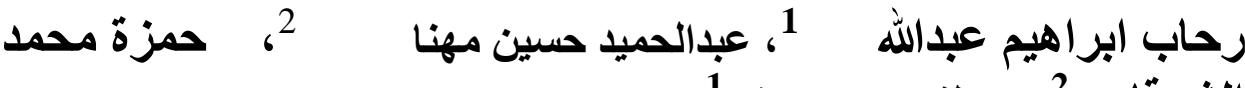

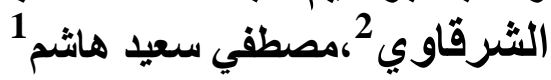

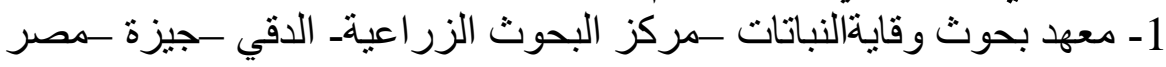

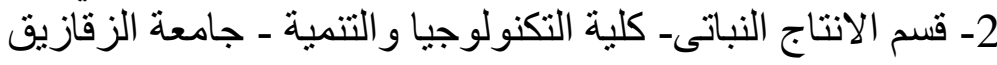

ـ ـ أجريت هذه الدر اسة بمركز الزقازيق محافظة الثرقية خلال الموسمين الزر اعيين

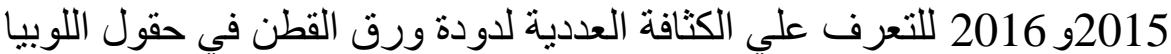

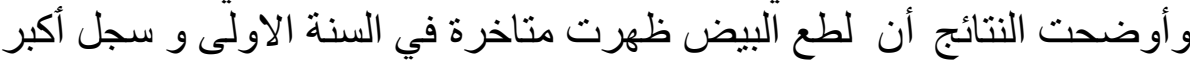

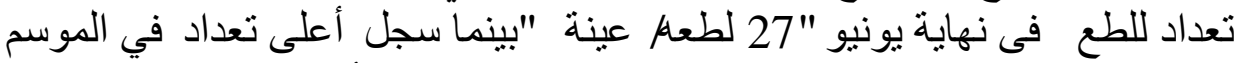

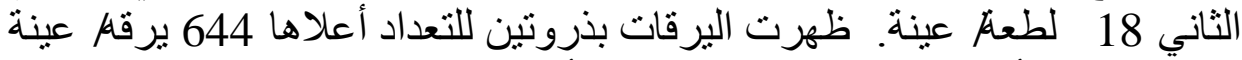

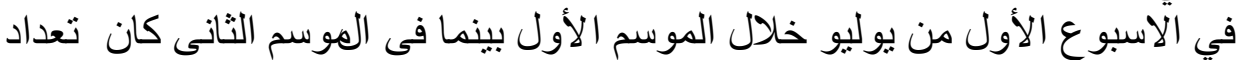

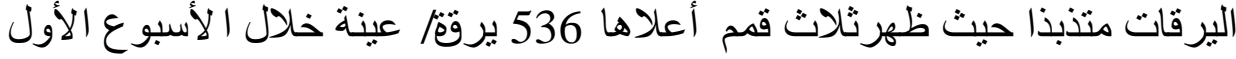

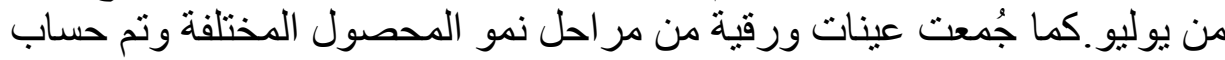

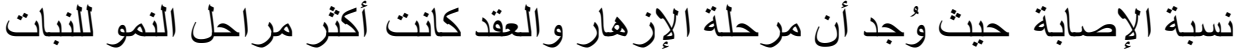

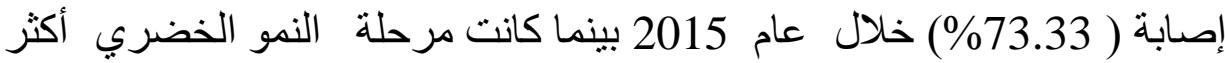
مر احل نمو المحصول إصابة عام 2016.

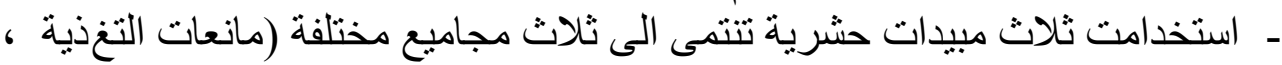

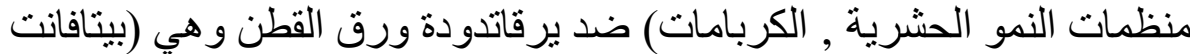

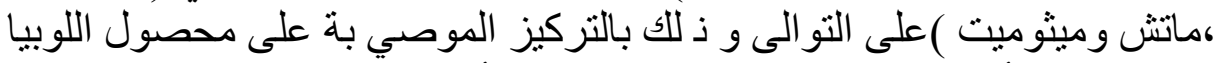

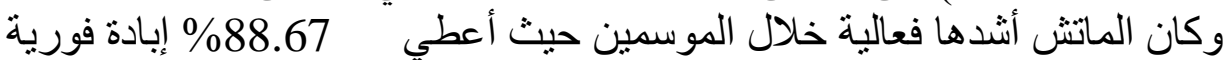
و 92.44\% أثر باقى يلية البيتافانت ، بينما كان الميثوميت أقل هذه المبيدات

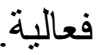
التوصية: بمعرفة عدد الأجيال للآفة على نبات اللوبيا يمكن استخدام نلك في برنامج بلامج

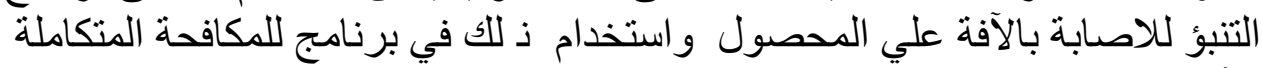

